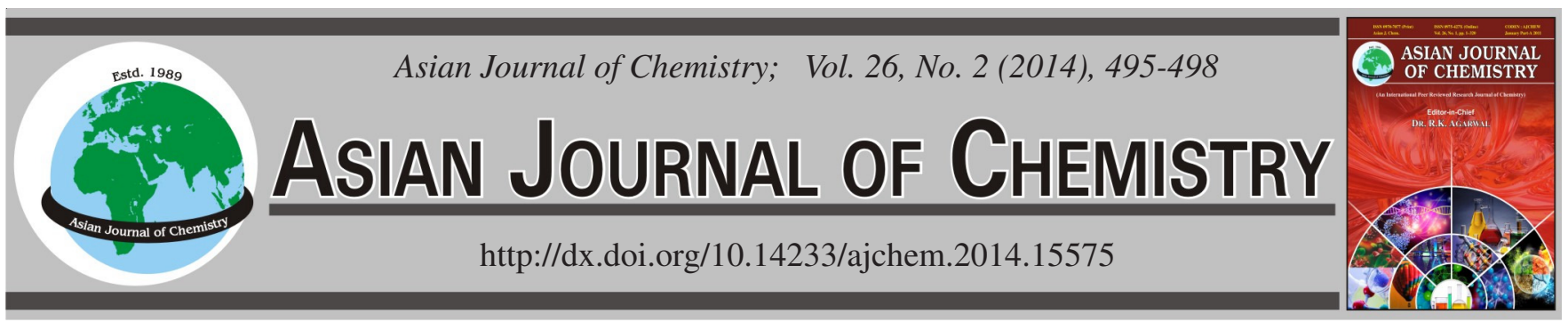

\title{
Conversion Mechanism of Toxic Hydrogen Cyanide by Magnesium Oxide at High Temperatures
}

Yingying Xiong, Xuebin Wang ", Limeng Zhang, Zhongfa Hu, Yanqing Niu and Houzhang Tan

MOE Key Laboratory of Thermo-Fluid Science and Engineering, School of Energy and Power Engineering, Xi'an Jiaotong University, Xi'an 710049, P.R. China

*Corresponding author: E-mail: wxb005@mail.xjtu.edu.cn

Received: 4 April 2013;

Accepted: 28 May 2013;

Published online: 15 January 2014;

AJC-14574

\begin{abstract}
Hydrogen cyanide $(\mathrm{HCN})$ is the most important precursor of NOx in coal combustion and is also a high toxic production in coal chemical industry. In the present study, investigations on HCN converting using magnesium oxides was carried out in a fixed bed at 300-1273 K and the original $\mathrm{HCN}$ was produced by the pyrolysis of pyridine. Effects of temperature, volume space velocity and initial HCN concentration on HCN conversion were considered. Results showed that temperature was the major factor affecting HCN conversion and it undergoes different conversion mechanism in different temperature scale. With the formation of $\mathrm{CO}$ at $723 \mathrm{~K}$, HCN started to decrease and kept a constant value from 873 to $973 \mathrm{~K}$. After $973 \mathrm{~K}, \mathrm{HCN}$ decreased significantly and $\mathrm{CH}_{4}$ from the pyrolysis of pyridine also decreased, but $\mathrm{CO}$ disappeared at $973 \mathrm{~K}$. When temperature was higher than $1123 \mathrm{~K}, \mathrm{HCN}$ was converted totally. In the isothermal experiments, $\mathrm{N}_{2}$ was detected at $1123 \mathrm{~K}$ but not at temperatures lower than $923 \mathrm{~K}$ and the nitrogen element in $\mathrm{N}_{2}$ was equal to that in the removal of $\mathrm{HCN}$. It indicated that below $973 \mathrm{~K} \mathrm{MgO}$ removed $\mathrm{HCN}$ by the pathway $\mathrm{MgO}+2 \mathrm{HCN} \rightarrow \mathrm{MgCN}_{2}+\mathrm{CO}+\mathrm{H}_{2}$. However, $\mathrm{MgO}$ acted as catalyst at above $973 \mathrm{~K}$ and $\mathrm{HCN}$ was converted to $\mathrm{N}_{2}$ by the reaction $2 \mathrm{C}_{\mathrm{x}} \mathrm{Y}_{\mathrm{y}}+2 \mathrm{HCN} \stackrel{\mathrm{MgO}}{\longrightarrow} \mathrm{N}_{2}+(\mathrm{y}+1-\mathrm{z}) \mathrm{H}_{2}+2 \mathrm{C}_{\mathrm{x}+1} \mathrm{H}_{\mathrm{z}}$.
\end{abstract}

Keywords: Pyridine, HCN, MgO, Temperature, Coal.

\section{INTRODUCTION}

Emission of nitrogen oxides from solid fuel combustion causes significant threat to the environment ${ }^{1}$. Considerable investigations have indicated that metal elements play important role in forming nitrogen oxides ${ }^{2-6}$. Some studies indicate that metal element causes a significant decrease of $\mathrm{N}_{2} \mathrm{O}$ in fluidized bed combustion ${ }^{7,8}$, while others argue that the influence is little 9 . The effect of metal elements on the emission of nitrogen oxides from coal combustion is still confusing.

Compared with abundant researches on the direct effect of metal elements on nitrogen oxides, less attention has been paid on the mechanisms related to the effect of metal element on the hydrogen cyanide, which is recognized as a predominant intermediate precursor of nitrogen oxides in converting of nitrogen in coal ${ }^{10-12}$. Coal nitrogen including volatile nitrogen and char nitrogen translates into $\mathrm{HCN}$ firstly in the process of combustion and then $\mathrm{HCN}$ reacts with $\mathrm{O}_{2}$ to form nitrogen oxides, additionally, $\mathrm{HCN}$ can also reacted with nitrogen oxides and produced $\mathrm{N}_{2}$ by reburning.

In the process of coal pyrolysis or gasification, the calcium oxide additive inhibits $\mathrm{HCN}$ formation but promotes the nitrogen in coal conversion to $\mathrm{N}_{2}$ efficiently ${ }^{13-21}$. Therefore, the demonstration on the reaction mechanism between metal element and $\mathrm{HCN}$ is helpful to understand how metal element affects the emission of nitrogen oxides. Meanwhile, due to massive $\mathrm{HCN}$ from the coal chemical industry results in heavy toxicity, further study on the characterization of $\mathrm{HCN}$ reduction by metal element may also provide a new approach to solving the problem of $\mathrm{HCN}$ pollution ${ }^{22}$.

On the basis of previous study on the characteristics of $\mathrm{HCN}$ removal using $\mathrm{CaO}^{23}$, the present study mainly focuses on the mechanism of $\mathrm{HCN}$ converting by magnesium oxide, which is one of the low cost alkaline earth species. The effects of temperature, volume space velocity and initial HCN concentration are discussed. The original $\mathrm{HCN}$ was generated by the pyrolysis of pyridine and gaseous species $\left(\mathrm{CO}, \mathrm{HCN}, \mathrm{H}_{2}, \mathrm{CH}_{4}\right.$ and $\mathrm{N}_{2}$ ) were monitored quantitatively by using a Fourier transform infrared spectroscopy gas analyzer coupled with the gas chromatography.

\section{EXPERIMENTAL}

Concentrations of $\mathrm{HCN}, \mathrm{NO}, \mathrm{N}_{2} \mathrm{O}, \mathrm{CO}$ and $\mathrm{CH}_{4}$ in flue gas were detected on-line by DX-4000 FT-IR gas analyzer $(1.07 \mathrm{~L}$ gas analysis cell with a path of $5 \mathrm{~m}$, resolution of $8 \mathrm{~cm}^{-1}$, response time $<120 \mathrm{~s}$, wave-number range of 4200$900 \mathrm{~cm}^{-1}$ and scan frequency of 10 spectra/s), made in Helsinki. The lowest detectable concentration was $1 \mathrm{ppm}$ and the estimated 


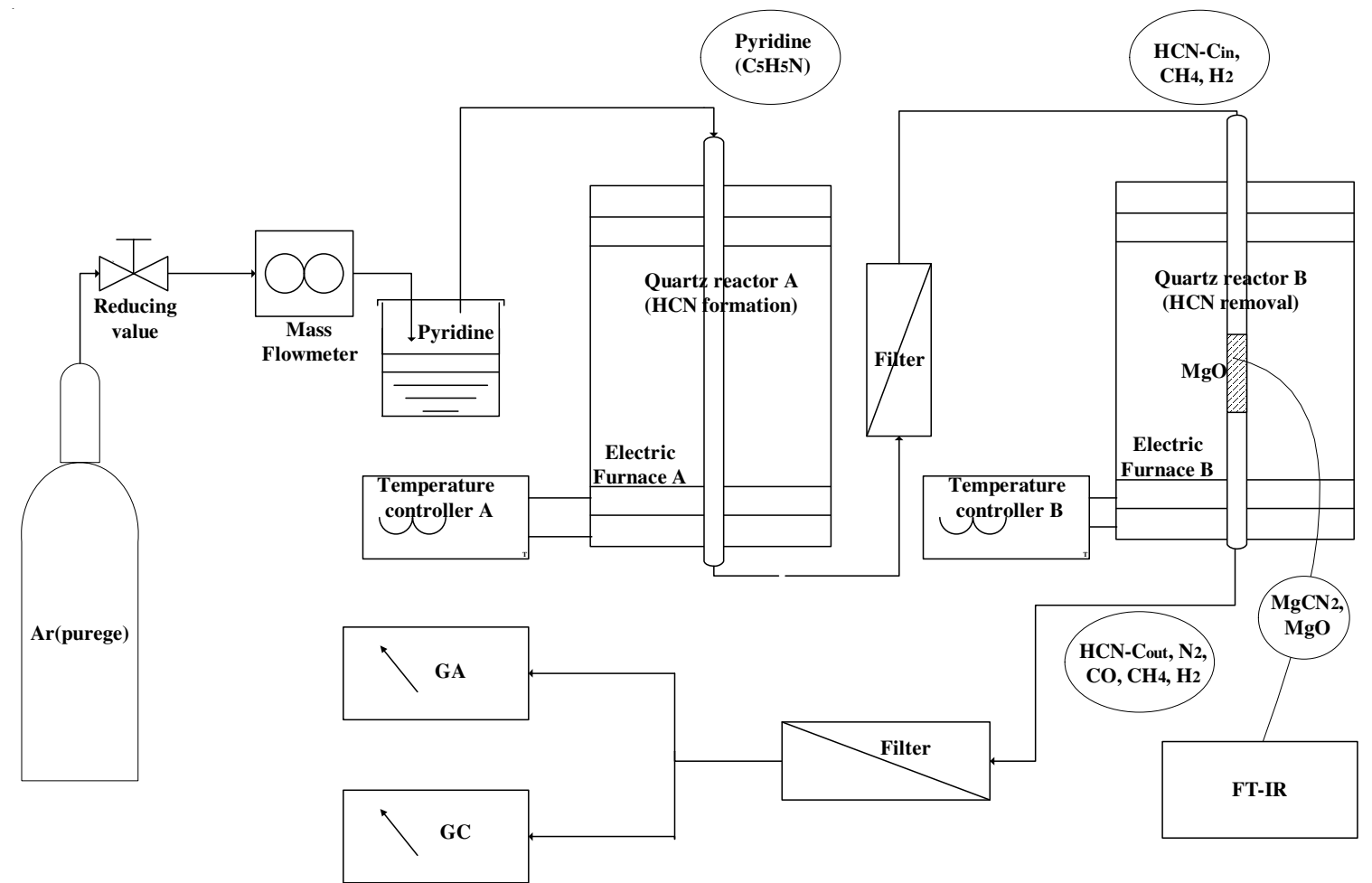

Fig. 1. Schematic diagram of experimental system for $\mathrm{HCN}$ formation and conversion

uncertainly limits of measurements were estimated to be within $\pm 2 \%$. Agilent-9800 GC (thermal conductivity detector, stationary phase of $5 \mathrm{~A}$ molecule sieve, carrier gas of argon, column of $4 \mathrm{~mm} \times 5 \mathrm{~m}$, column temperature of $341 \mathrm{~K}$ ) was used to quantify the concentration of $\mathrm{H}_{2}$ and $\mathrm{N}_{2}$.

HCN preparation (pyrolysis of pyridine): $\mathrm{HCN}$ is high toxic and is difficult to obtain its standard concentration gas, meanwhile, in the pyrolysis of the pyridine, $\mathrm{HCN}$ is generally believed to be the most important nitrogen-containing prod$\mathrm{uct}^{24}$. Therefore, in the presented work, pyridine has been chosen as the source of $\mathrm{HCN}$ and pyrolysis of pyridine was performed in quartz reactor A at $1273 \mathrm{~K}$. As shown in Fig. 1, volatile pyridine in vessel was carried out by high-purity argon (> $99.999 \%$ ). In order to guarantee the constant sample quantity, the flow rate of argon was controlled stable at 600 $\mathrm{mL} / \mathrm{min}$ by mass flow meter. The long-time detection for $\mathrm{HCN}$ proved that the yield of gaseous species was stable and pyrolysis of pyridine can provide reliable $\mathrm{HCN}$ for the followed experiment of $\mathrm{HCN}$ removal. Before entering reactor $\mathrm{B}$, the gaseous products from pyridine pyrolysis passed through a filter filled with $\mathrm{CaCl}_{2}$ to remove water steam and residual pyridine from reactor $\mathrm{A}$.

HCN converting by MgO: The experiment of $\mathrm{HCN}$ converting was carried out in quartz reactor $\mathrm{B}$, which was 20 $\mathrm{mm}$ in inner diameter and $1000 \mathrm{~mm}$ in length. The electric furnace with a $\mathrm{SiC}$ tube as electrothermal element supplied heat to the reactor and could continuously work at temperature as high as $1473 \mathrm{~K}$ and the constant-temperature heating zone was longer than $600 \mathrm{~mm}$. A Ni-Cr/Ni-Si thermocouple controlled by SHIMADEN FP93 PID regulator was used to measure the reaction zone temperature with a precision of $\pm 2 \mathrm{~K}$. Analytically pure $\mathrm{MgO}$ powder that was squeezed in the mold at $5 \mathrm{MPa}$ for
$5 \mathrm{~min}$ and then crushed and sieved to $1.0-1.7 \mathrm{~mm}$, was placed on an orifice in the middle of the reactor $\mathrm{B}$.

\section{RESULTS AND DISCUSSION}

Conversion mechanisms of $\mathrm{HCN}$ under different temperature scales: Fig. 2 illustrates the effect of temperature on the outlet concentration of $\mathrm{HCN}\left(\mathrm{C}_{\text {out }}\right), \mathrm{CO}$ and $\mathrm{CH}_{4}$ in the temperature programmed experiments under the condition that initial $\mathrm{HCN}$ concentration $\left(\mathrm{C}_{\text {in }}\right)$ was around $232 \mathrm{ppm}$ and $\mathrm{MgO}$ stacking thickness was $12 \mathrm{~mm}$.

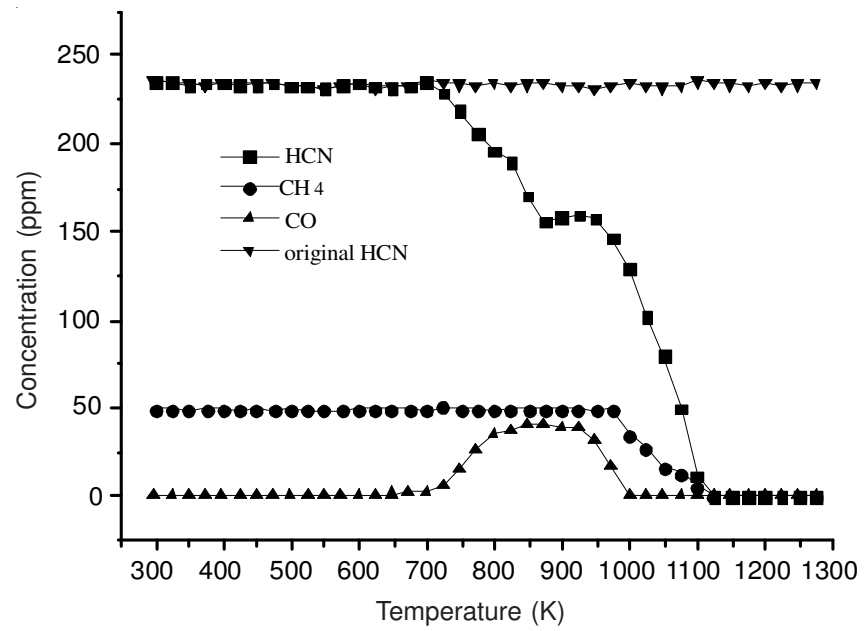

Fig. 2. Profile of gaseous species $\left(\mathrm{HCN}, \mathrm{CH}_{4}, \mathrm{CO}\right)$ at different temperatures

Fig. 2 showed the reduction of HCN started at $723 \mathrm{~K}$. When the temperature increased to $873 \mathrm{~K}, \mathrm{C}_{\text {out }}$ decreased to $156 \mathrm{ppm}$ and kept unchanged from 873 to $973 \mathrm{~K}$. When the temperature further increased to $1123 \mathrm{~K}, \mathrm{C}_{\text {out }}$ sharply fell to 
$0 \mathrm{ppm}$. In response to $\mathrm{HCN}$ reduction, the formation of $\mathrm{CO}$ also began at $723 \mathrm{~K}$, but $\mathrm{CO}$ only existed in the region of 673$973 \mathrm{~K}$. Lagging behind the change of $\mathrm{HCN}$ and $\mathrm{CO}, \mathrm{CH}_{4}$ did not decrease up to $973 \mathrm{~K}$ and fell to $0 \mathrm{ppm}$ at $1123 \mathrm{~K}$ along with the further decrease in $\mathrm{HCN}$.

Table-1 shows the profile of gaseous species at three typical temperatures $(723,923$ and $1123 \mathrm{~K})$ in isothermal experiments. Hydrogen mainly formed by pyridine pyrolysis in reactor A and accounted for the highest percentage. With the increase in temperature, the concentration of $\mathrm{H}_{2}$ continued to rise. At the lower temperature of 723 and $923 \mathrm{~K}, \mathrm{~N}_{2}$ was not present. When the temperature increased to even higher than $1123 \mathrm{~K}$, the amount of nitrogen in form of $\mathrm{N}_{2}$ was nearly equal to that in the initial $\mathrm{HCN}$ and there was no $\mathrm{CH}_{4}$ and $\mathrm{CO}$, which might mean that all the $\mathrm{HCN}$ had been converted to $\mathrm{N}_{2}$. At $923 \mathrm{~K}$, although $\mathrm{HCN}$ had decreased to $159 \mathrm{ppm}$, there was no formation of $\mathrm{N}_{2}$. It was estimated that $\mathrm{HCN}$ may react with $\mathrm{MgO}$ to form $\mathrm{MgCN}_{2}$ on the basis of previous study ${ }^{23}$.

TABLE-1

PROFILES OF GASEOUS SPECIES AT THREE TYPICAL TEMPERATURES DETECTED USING FTIR AND GC

\begin{tabular}{ccccccc}
\hline Temp. & Inlet conc. of & \multicolumn{5}{c}{ Outlet conc. of several species (ppm) } \\
\cline { 3 - 7 }$(\mathrm{K})$ & $\mathrm{HCN}(\mathrm{ppm})$ & $\mathrm{HCN}$ & $\mathrm{CH}_{4}$ & $\mathrm{H}_{2}$ & $\mathrm{~N}_{2}$ & $\mathrm{CO}$ \\
\hline 723 & 232 & 229 & 50 & 525 & 0 & 7 \\
923 & 232 & 159 & 53 & 573 & 0 & 41 \\
1123 & 232 & 0 & 0 & 886 & 125 & 0 \\
\hline
\end{tabular}

Results from Fig. 2 denote that $\mathrm{MgO}$ was highly efficient to remove $\mathrm{HCN}$ at high temperatures. Table-1 has also demonstrated that the components of gas species changed significantly at different temperatures, which indicates that the reaction mechanism between $\mathrm{MgO}$ and $\mathrm{HCN}$ may change with temperature.

$\mathrm{CO}$ existed only in the range of 673-973 K. Because experiments were performed in the inert atmosphere, there was no oxygen whether in pyridine or in its pyrolytic products from reactor $\mathrm{A}$, so the oxygen in $\mathrm{CO}$ could only come from $\mathrm{MgO}$.

At a lower temperature of $923 \mathrm{~K}, \mathrm{HCN}$ concentration decreased, but there was no other nitrogen-containing species detected. Then the other nitrogen was suggested in the solid residues. Therefore, $\mathrm{HCN}$ and $\mathrm{MgO}$ might react by eqn. 1:

$$
\mathrm{MgO}+2 \mathrm{HCN} \rightarrow \mathrm{MgCN}_{2}+\mathrm{CO}+\mathrm{H}_{2}
$$

However, when the temperature increased to higher than $973 \mathrm{~K}$, $\mathrm{CO}$ disappeared, $\mathrm{CH}_{4}$ began to fall and $\mathrm{HCN}$ also started its second round decrease (Fig. 2). When the temperature was higher than $1123 \mathrm{~K}, \mathrm{HCN}, \mathrm{CO}$ and $\mathrm{CH}_{4}$ disappeared totally and there were only $\mathrm{H}_{2}$ and $\mathrm{N}_{2}$ detected. It is concluded that at a temperature higher than $923 \mathrm{~K}$, all the nitrogen in $\mathrm{HCN}$ had been transformed into $\mathrm{N}_{2}$, there was no nitrogen left in solid residues. As seen from Table-1, at $1123 \mathrm{~K}$ the change of $\mathrm{HCN}$ concentration between inlet and outlet was $232 \mathrm{ppm}$ and the outlet $\mathrm{N}_{2}$ concentration was $125 \mathrm{ppm}$. Consequently, at higher temperature $1123 \mathrm{~K}$ the ratio of $\mathrm{HCN} / \mathrm{N}_{2}$ was probably equal to $2: 1$ and the reaction mechanism of $\mathrm{HCN}$ and $\mathrm{MgO}$ at a higher temperature was presumed to be like eqn. 2 :

$$
2 \mathrm{C}_{\mathrm{x}} \mathrm{Y}_{\mathrm{y}}+2 \mathrm{HCN} \stackrel{\mathrm{MgO}}{\longrightarrow} \mathrm{N}_{2}+(\mathrm{y}+1-\mathrm{z}) \mathrm{H}_{2}+2 \mathrm{C}_{\mathrm{x}+1} \mathrm{H}_{\mathrm{z}}
$$

where $\mathrm{C}_{x} \mathrm{H}_{y}$ and $\mathrm{C}_{x+1} \mathrm{H}_{z}$ only refer to a general designation of hydrocarbon before and after passing through the $\mathrm{MgO}$ layer in reactor $\mathrm{B}$, because the species of hydrocarbon from pyridine pyrolysis in reactor A were complex and there was only $\mathrm{CH}_{4}$ detected and analyzed representatively in the process of experiments. This is similar to the conclusion that $\mathrm{CaO}$ catalyzes an efficient conversion reaction of char-nitrogen to $\mathrm{N}_{2}{ }^{9,25}$.

Effect of volume space velocity (SV) and initial $\mathrm{HCN}$ concentration $\left(\mathbf{C}_{\mathrm{in}}\right)$ on the converting of $\mathrm{HCN}$ : To characterize the effective time of $\mathrm{HCN}$ passing through the $\mathrm{MgO}$ layer, volume space velocity $\left(\mathrm{h}^{-1}\right)$ was calculated by eqn. 3 .

$$
\mathrm{SV}=\frac{\mathrm{Q}}{\mathrm{V}}
$$

where $\mathrm{Q}$ is the carrier gas flow rate $\left(\mathrm{m}^{3} / \mathrm{h}\right), \mathrm{V}$ is the stacking volume $\left(\mathrm{m}^{3}\right)$.

The converting rate of $\mathrm{HCN}$ was defined as $\eta_{\mathrm{HCN}}$ according to the difference between $\mathrm{C}_{\text {in }}$ and $\mathrm{C}_{\text {out }}$ of reactor $\mathrm{B}$ by eqn. 4 .

$$
\eta_{\mathrm{HCN}}=\frac{\mathrm{C}_{\text {in }}-\mathrm{C}_{\text {out }}}{\mathrm{C}_{\text {in }}} \times 100 \%
$$

The effect of SV on $\eta_{\mathrm{HCN}}$ were carried out with stable argon flow rate $(600 \mathrm{~mL} / \mathrm{min})$ and $\mathrm{C}_{\text {in }}(234 \mathrm{ppm})$ at $1123 \mathrm{~K}$. It could be seen from Fig. 3 that with increased SV, $\eta_{\mathrm{HCN}}$ decreased. HCN could be totally converted when the value of $\mathrm{SV}$ is lower than $10000 \mathrm{~h}^{-1}$.

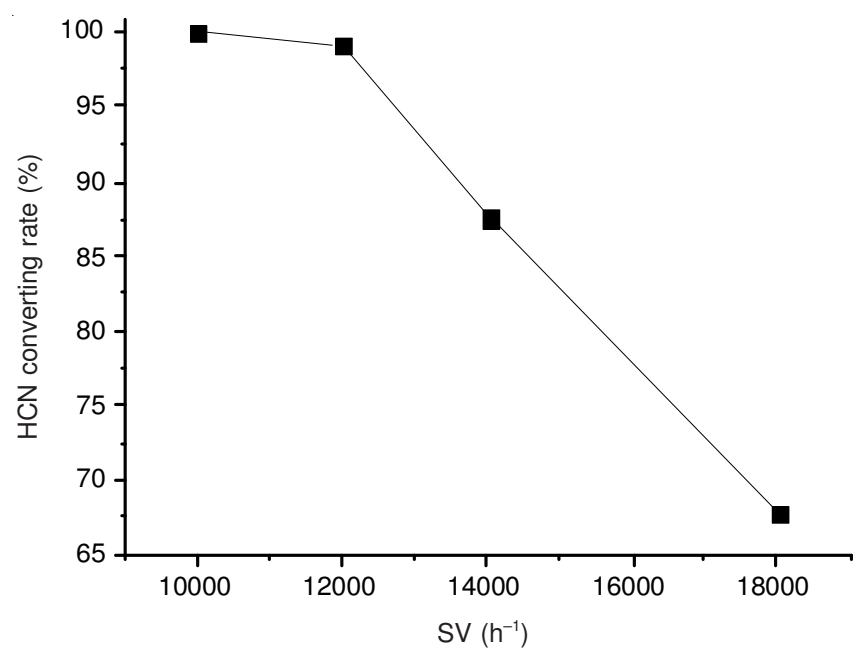

Fig. 3. Effect of volume space velocity on the coverting rate of $\mathrm{HCN}$

Meanwhile, the effect of SV on the critical temperature, at which the $\eta_{\mathrm{HCN}}$ was $100 \%$, was illustrated in Fig. 4. It could be seen that with the increasing in $\mathrm{SV}$, the minimum temperature of $\mathrm{HCN}$ complete converting increased. In addition, the effect of $\mathrm{C}_{\mathrm{in}}$ on $\eta_{\mathrm{HCN}}$ were carried out with stable SV $\left(10000 \mathrm{~h}^{-1}\right)$ at $1123 \mathrm{~K}$. Table- 2 showed that the $\eta_{\mathrm{HCN}}$ was over $99 \%$ and even $100 \%$. The HCN could be converted totally with stable $\mathrm{SV}\left(10000 \mathrm{~h}^{-1}\right)$ at $1123 \mathrm{~K}$.

TABLE-2

RELATION BETWEEN HCN CONVERSION

RATE AND INITIAL HCN CONCENTRATION

\begin{tabular}{llllccc}
$\mathrm{C}_{\text {in }}(\mathrm{ppm})$ & 123.5 & 243 & 305 & 371.4 & 462.3 & 501 \\
$\eta_{\mathrm{HCN}}(\%)$ & 99.17 & 100 & 100 & 100 & 100 & 100 \\
\hline
\end{tabular}




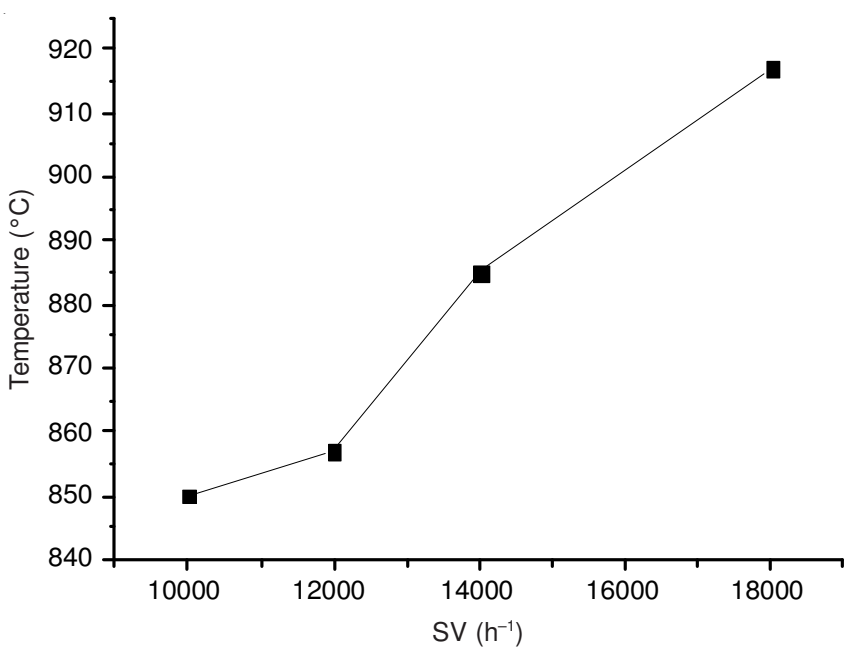

Fig. 4. Effect of volume space velocity on the minimum full converting temperature $\left(\eta_{\mathrm{HCN}}\right.$ was $\left.100 \%\right)$

\section{Conclusion}

The effects of temperature, volume space velocity (SV) and initial $\mathrm{HCN}$ concentration on the removal of HCN using $\mathrm{MgO}$ are investigated and the main conclusions are summarized as:

- The conversion of HCN starts at $723 \mathrm{~K}$ and keeps unchanged from 873 to $973 \mathrm{~K}$. When the temperature further increases to $1123 \mathrm{~K}, \mathrm{HCN}$ disappears. In response to $\mathrm{HCN}$ reduction, the formation of $\mathrm{CO}$ also begins at $723 \mathrm{~K}$, but $\mathrm{CO}$ only exists in the region of 673-973 K. Methane does not decrease until $973 \mathrm{~K}$ and disappears at $1123 \mathrm{~K}$. Nitrogen gas is detected until $1123 \mathrm{~K}$ and the nitrogen in $\mathrm{N}_{2}$ was just equal to that in the removal of $\mathrm{HCN}$.

- The mechanism of $\mathrm{HCN}$ removal varies at different temperature scales. At a lower temperature than $923 \mathrm{~K}$, the mechanism of HCN removal is indicated as:

$$
\mathrm{MgO}+2 \mathrm{HCN} \rightarrow \mathrm{MgCN}_{2}+\mathrm{CO}+\mathrm{H}_{2}
$$

However, when the temperature is higher than $973 \mathrm{~K}$, the reaction mechanism between $\mathrm{HCN}$ and $\mathrm{MgO}$ is

$$
2 \mathrm{C}_{\mathrm{x}} \mathrm{Y}_{\mathrm{y}}+2 \mathrm{HCN} \stackrel{\mathrm{MgO}}{\longrightarrow} \mathrm{N}_{2}+(\mathrm{y}+1-\mathrm{z}) \mathrm{H}_{2}+2 \mathrm{C}_{\mathrm{x}+1} \mathrm{H}_{\mathrm{z}}
$$

- With the increased volume space velocity the HCN removal efficiency decreases, while the minimum temperature at which $\mathrm{HCN}$ can be totally removed increases. Additionally, $\mathrm{HCN}$ removal efficiency can reach up to $100 \%$.

\section{ACKNOWLEDGEMENTS}

This study was supported by the National Natural Science Foundation of China (Nos. 51376147 and 51306142).

\section{REFERENCES}

1. J.M. Beer, Prog. Energy Combust. Sci., 26, 301 (2000).

2. A.N. Hayhurst and A.D. Lawrence, Combust. Flame, 105, 511 (1996).

3. A.A. Patsias, W. Nimmo, B.M. Gibbs and P.T. Williams, Fuel, 84, 1864 (2005).

4. B.J. Zhong and H. Tang, Combust. Flame, 149, 234 (2007).

5. W. Nimmo, A.A. Patsias, W.J. Hall and P.T. Williams, Ind. Eng. Chem. Res., 44, 4484 (2005)

6. F. Guo and W.C. Hecker, Effects of $\mathrm{CaO}$ and Burnout on the Kinetics of NO Reduction by Beulah Zap Char, Twenty-Sixth Symposium (International) on Combustion, Vol. 1-2, pp. 2251-57 (1996).

7. E. Sasaoka, N. Sada, K. Hara, M.A. Uddin and Y. Sakata, Ind. Eng. Chem. Res., 38, 1335 (1999).

8. P. Abelha, I. Gulyurtlu and I. Cabrita, Fuels, 22, 363 (2008)

9. M.A. Wojtowicz, J.R. Pels and J.A. Moulijn, Fuel Process. Technol., 34, 1 (1993).

10. P. Dagaut, P. Glarborg and M.U. Alzueta, Progr. Energy Combust. Sci., 34, 1 (2008).

11. P. Glarborg, A.D. Jensen and J.E. Johnsson, Progr. Energy Combust. Sci., 29, 89 (2003).

12. S.C. Hill and L.D. Smoot, Progr. Energy Combust. Sci., 26, 417 (2000).

13. A. Jensen, J.E. Johnsson and K. Dam-Johansen, AIChE J., 43, 3070 (1997).

14. Y. Ohtsuka, T. Watanabe, K. Asami and H. Mori, Energy Fuels, 12, 1356 (1998)

15. Y. Ohtsuka, W. Zhiheng and E. Furimsky, Fuel, 76, 1361 (1997).

16. H.-F. Liu, Y.-H. Liu, Y.-H. Liu and D.-F. Che, J. Fuel Chem. Technol., 36, 134 (2008).

17. S. Schäfer and B. Bonn, Fuel, 81, 1641 (2002).

18. J.-I. Hayashi, K. Kusakabe, S. Morooka, M. Nielsen and E. Furimsky, Energy Fuels, 9, 1028 (1995).

19. H. Mori, K. Asami and Y. Ohtsuka, Energy Fuels, 10, 1022 (1996).

20. Y. Ohtsuka, H. Mori, K. Nonaka, T. Watanabe and K. Asami, Energy Fuels, 7, 1095 (1993).

21. N. Tsubouchi, Y. Ohshima, C. Xu and Y. Ohtsuka, Energy Fuels, 15, 158 (2001)

22. X.R.B. Jinfeng, Chemical Products-Technology of Coal, Beijing: Metallurgical Industry Press (2003).

23. H. Tan, X. Wang, C. Wang and T. Xu, Energy Fuels, 23, 1545 (2009).

24. J.H. Kiefer, Q. Zhang, R.D. Kern, J. Yao and B. Jursic, J. Phys. Chem. A, 101, 7061 (1997).

25. N. Tsubouchi, M. Abe, C.B. Xu and Y. Ohtsuka, Energy Fuels, 17, 940 (2003). 